\title{
PÄÄKIRJOITUS
}

\author{
Eliza Kraatari
}

\section{ULOS TUULIKAAPISTA, KULTTUURIPOLITIIKKA!}

Kulttuuritoimintoihin osallistumisen positiivista merkitystä hyvinvoinnille on toistettu pitkään, ja tätä merkityksellisyyttä on verifioitu tutkimuksenkin voimin. Tärkeää vaikuttavuutta todentavassa tutkimuksessa on usein ollut hyvinvointivaikutusten mittattavuus - tai kenties paremminkin tuon mitattavuuden ongelmat.

Niinpä kulttuuripolitiikan ydinosaa olevat tavoitteet, kulttuuriosallistuminen ja kulttuuritoimintojen saavutettavuus (laajasti ymmärrettynä), ovat tupsahtaneet epistemologiseen noidankehään, jossa näitä politiikkatavoitteita perustellaan tiedolla, jonka tuottamisessa on ajoin suuria vaikeuksia ja jonka perusteluvoima voi siksi jäädä heikoksi sikäli kuin tutkimustietoa poliittishallinnollisissa elimissä ylipäänsä ehditään lukea.

Tiedon tarpeet kulttuuripolitiikan alalla ovat kuitenkin todellisia: tarvitaan tietoa toimintaympäristöjen muutoksista ja näiden muutosten vaikutuksista ihmisten tarpeisiin myös kulttuuritoimintojen osalta. Erilaisia seurantatietoja kaivataan, mutta riski sortua numeroiden magiaan on suuri, etenkin jos "indikaattoriperusteisuus" on vallitseva tietokäsityksen muoto. Eräässä tätä indikaattorikeskeisyyttä ironisoineessa aloitteessa suositettiin humoristisesti "osuuskaupan tuulikaappiin mittaria", jonka avulla kansalaiset voisivat sitten itse indikoida, mikä heidän päivän hyvinvointikokemuksen lähteenä on ollut, kulttuuripalvelut vai voittolinja hedelmäpelissä.

Tässä vuosikirjassa Anu Laukkanen, Anne Teikari ja Marjaana Colliander syventävät etäkonserttien tapausesimerkin kautta kriittisiä näkökulmia saavutettavuuteen. Artikkeli tarjoaa lukijalle pohdittavaksi muun muassa sen, onko kulttuurin saavutettavuus itse asiassa "onnellisuusobjekti", joka yhtäältä lupailee syrjäytysmisuhanalaisille figuureille osallisuutta yhteiskuntaan ja toisaalta tarjoilee kulttuuripalveluiden tuottajille itselleen antroposofista euforiakokemusta.

Sirkku Kotilaisen ja Satu Olkkosen artikkeli puolestaan avaa mahdollisuuksia tiedon yhteiseen tekemiseen, kun dokumenttiteatterin kautta käydään kanssatutkijuuten yhdessä nuorten kanssa. Artikkelissa 
nousee esiin muun muassa eräiden tukijärjestelmien kontrolloivuus, jolloin näennäisen voimavaraistavat keinot voivat kääntyä itseään vastaan.

Yhdessä tarkasteltuna nämä artikkelit kutsuvat arvioimaan kriittisesti kulttuuripoliittisia ihmisenä ja kansalaisena olemisen reunaehtoja: mitkä tahot määrittelevät ja miten määrittyvät vaillinaisuus, tarvitsevuus tai kykeneväisyys kulttuurisen yhteisön jäseninä ja kansalaisina? Tunkeutuvatko kulttuuripolitiikan normaalit läpi moninaisuuden diskurssin verhoista? Tähän näkökulman antaa myös Katri Talaskiven puheenvuoro Suomessa uusien kielivähemmistöjen kirjailijoista.

Historiallinen näkökulma teknologisiin uutuuksiin kulttuuristen elämysten saavutettavuuden mahdollistajina antaa perspektiiviä aikamme digihuumaan. Aleksi Lohtajan ja Taneli Viitahuhdan luenta Walter Benjaminin ajatuksista taideteoksen uusinnettavuudesta paitsi tuottaa uutta näkökulmaa Benjamin-tutkimukseen myös tarjoaa analyyttista syvyyttä esteettisten kokemusten ja niiden välittämisen ymmärtämiseen. Herääkin kysymys, miten teknologiset mahdollisuudet tässä ajassa oikeastaan kohtaavat kulttuuritoimintojen käyttäjät, osallistujat. Tuottavatko ne läpinäkyvyyttä yhteiskunnallisiin ja kulttuurisiin muutoksiin vai pelkästään hymynaama-mittareita tuulikaappeihin?

Samalla kulttuuripolitiikan tutkimuksen parissa on reflektoitava aktiivisesti, mihin tutkimushuomiota kiinnitetään, miten tietoa tuotetaan ja millä keinoin sitä jaetaan. Tämä tehtävä on yhteinen, eikä valmiita vastauksia tietystikään ole. Kulttuuripolitiikan tutkimuksen vuosikirjassa ovia on moneen suutaan ja kynnys matala. Avoimella julkaisualustalla tilaa riittää erilaisille, monialaisille ja kriittisille, puntaroiduille argumenteille sekä pohdituille puheenvuoroille.

Hyviä lukuhetkiä ja kirjoitusintoa toivottaen

Eliza Kraatari

Kulttuuripolitiikan tutkimuksen vuosikirjan 2017 päätoimittaja 